\title{
Manipulasi Gambar dengan Transfer Gaya Menggunakan Convolutional Neural Network
}

\author{
Rakhmi Khalida*, Khairunnisa Fadhilla Ramdhania \\ Ilmu Komputer, Informatika, Universitas Bhayangkara Jakarta Raya, Bekasi, Indonesia \\ Email: 1,"rakhmi.khalida@dsn.ubharajaya.ac.id, ${ }^{2}$ khairunnisa.fadhilla@dsn.ubharajaya.ac.id \\ Email Penulis Korespondensi: rakhmi.khalida@dsn.ubharajaya.ac.id \\ Submitted: 17/12/2021; Accepted: 26/12/2021; Published: 31/12/2021
}

\begin{abstract}
Abstrak-Baru-baru ini komputer mampu menghasilkan foto-foto yang memungkinkan user untuk mengomposisi foto selfie dengan lukisan Van Gogh. Terinspirasi oleh kekuatan convolusional neural networks (CNN), pertama kali mempelajari cara menggunakan $\mathrm{CNN}$ untuk mereproduksi gaya lukisan terkenal dipadukan dengan gambar potret diri. Metode yang digunakan disebut transfer neural network. Namun, versi awal neural network memiliki masalah optimisasi, membutuhkan ratusan atau ribuan iterasi untuk melakukan transfer gaya yang dikombinasi dengan satu gambar. Untuk mengatasi in-efisiensi ini peneliti mengembangkan metode transfer gaya CNN PerStyle-Per-Model (PSPM). Pengembangan transfer gaya menggunakan deep neural network disebut juga NST dengan melatih model VGG-16 untuk mengubah gambar apa pun dalam satu umpan, foward propagation. Model yang terlatih dapat menyesuaikan dengan mode gambar apa pun hanya dengan satu iterasi bukan ribuan iterasi melalui jaringan dan untuk mendapatkan hasil transfer gaya yang memiliki gaya stabil nilai gaya estetika yang objektif .
\end{abstract}

Kata Kunci: Gambar Gaya; Gambar Konten; Lukisan; Transfer Gaya

Abstract-Recently computers have been able to produce photographs that allow users to compose selfies with van Gogh paintings. Inspired by the power of convolutional neural networks (CNN), he first learned how to use $\mathrm{CNN}$ to reproduce famous painting styles combined with self-portrait images. The method used is called a neural network transfer. However, early versions of neural networks had optimization problems, requiring hundreds or thousands of iterations to transfer forces combined with a single image. To overcome this in-efficiency, researchers developed the CNS-style PerStyle-Per-Model (PSPM) transfer method. The development of force transfer using a deep neural network is also called NST by training the VGG-16 model to change any image in one feed, foward propagation. A trained model can adjust to any drawing mode with just one iteration instead of thousands of iterations over the network and to get the most objective possible style of transfer.

Keywords: Image Style; Image Content; Painting; Transfer Style

\section{PENDAHULUAN}

Di masa lalu, menggambar ulang gambar dalam gaya tertentu membutuhkan seniman yang terlatih dan banyak waktu. Sejak pertengahan 1990-an, teori-teori seni di balik karya seni yang cantik telah menarik perhatian, tidak hanya para seniman tetapi banyak peneliti ilmu komputer. Ada banyak studi literatur dan teknik yang mengeksplorasi cara mengubah gambar menjadi karya seni sintetis salah satunya adalah rendering non-fotorealistik (NPR) [1],[2],[3] yang menginspirasi, dan saat itu adalah bidang yang diteliti oleh komunitas grafis komputer. Namun, algoritma penataan NPR ini dirancang untuk gaya artistik tertentu [3], [4] dan tidak bisa mudah diperluas ke gaya lain.

Baru-baru ini komputer mampu menghasilkan foto-foto yang memungkinkan user untuk mengomposisi foto selfie dengan lukisan Van Gogh. Dahulu mungkin pernah membayangkan seperti apa foto selfie jika dilukis oleh seorang seniman terkenal, maka transfer gaya adalah teknik computer vision yang merubah hal ini menjadi kenyataan. Transfer gaya adalah teknik computer vision yang mengambil dua gambar yaitu yang disebut gambar konten dan gambar referensi gaya lalu memadukan keduanya sehingga gambar keluaran yang dihasilkan tetap mempertahankan elemen inti dari gambar konten, tetapi tampak hasil keluaran gambar seperti "dikuas dengan cat" dengan gaya dari gambar referensi gaya, hal ini dapat dilihat contohnya pada Gambar 1.

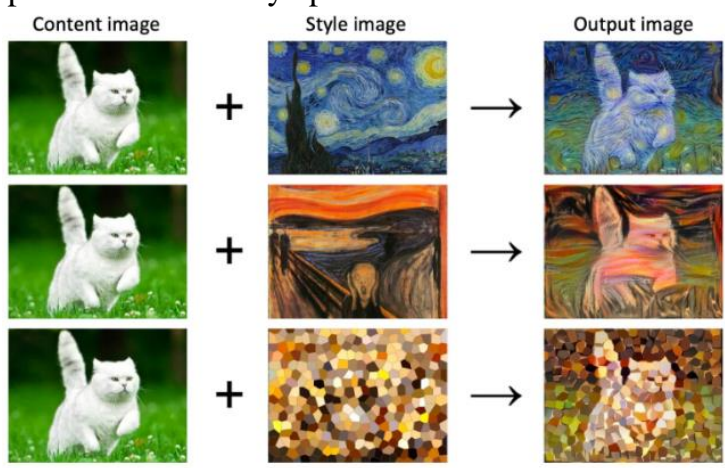

Gambar 1. Gambar Kucing dengan Transfer Gaya

1 disebut transfer neural network telah mengubah apa yang seperti tidak mungkin. Tranfer gaya menggunakan deep neural network untuk mendukung transformasi ini. Neural network bertugas untuk mengekstraksi fitur statistik gambar yang terkait dengan konten dan gaya sehingga dapat mengukur seberapa baik transfer gaya yang dihasilkan. 
Deep learning merupakan serangkaian metode yang terdiri dari multi-layer neural networks sederhana yang memungkinkan sistem untuk menyelesaikan masalah-masalah yang membutuhkan pemahaman yang setara dengan kecerdasan manusia.

Namun, versi awal neural network [4] bukan tanpa kekurangan, transfer gaya awal memiliki masalah optimisasi, membutuhkan ratusan atau ribuan iterasi untuk melakukan transfer gaya yang dikombinasi dengan satu gambar. Untuk mengatasi in-efisiensi ini, peneliti [5],[6],[7] mengembangkan apa yang disebut neural transfer style (NST). Pengembangan NST juga menggunakan deep neural network tetapi melatih model mandiri untuk mengubah gambar apa pun dalam satu umpan, foward propagation. Model yang terlatih dapat menyesuaikan dengan mode gambar apa pun hanya dengan satu iterasi bukan ribuan iterasi melalui jaringan.

Penelitian transfer gaya telah banyak dicoba pada berbagai peneliti. Saat ini NST memiliki dua kategori yaitu Rekonstruksi Gambar Online Berbasis Optimasi-Gambar (IOB-IR) dan Rekonstruksi Gambar Offline Berbasis Model-Optimisation (MOB-IR). Versi awal neural network [4] adalah transfer gaya dengan mengoptimalkan secara iteratif suatu gambar. Keterbatasan umum dari algoritma IOB-IR adalah bahwa mereka mahal secara komputasi, karena prosedur optimasi gambar secara iteratif. Peneliti [5],[6],[7] mengoptimalkan model generatif offline dan menghasilkan gambar transfer gaya dengan umpan maju foward propagation atau MOB-IR. Algoritma mereka secara signifikan mempercepat proses rekonstruksi gambar.

Rekonstruksi Gambar Offline Berbasis Model-Optimisation (MOB-IR)

a. PerStyle-Per-Model (PSPM)

Sebuah penelitian [6] yang pertama melatih jaringan saraf independen untuk menyesuaikan dengan mode gambar dalam sekali, umpan maju. Model VGG16 besar yang telah dilatih sebelumnya di ImageNet digunakan untuk ekstraktor fitur, dan jaringan encoder-decoder yang relatif kecil berfungsi sebagai jaringan transfer. Dalam pendekatan ini, jaringan transfer tunggal dilatih untuk setiap gaya yang diinginkan. Hasil transfer gaya masih didapat kurang stabil dengan perubahan signifikan resolusi gambar input.

b. Multiple-StylePer-Model

Pada 2017, [8] setahun setelah teknik fast neural transfer diterbitkan, para peneliti di Google memperluas teknik untuk memungkinkan jaringan transfer tunggal untuk menghasilkan gambar dalam berbagai gaya dan bahkan memadukan lebih dari satu gaya bersama-sama. Jaringan ini mengambil gambar konten sebagai input, bersama dengan vektor tambahan yang memberi tahu jaringan, berapa banyak gaya masing-masing untuk diterapkan pada gambar komposisi. Jadi misalnya, seorang model dapat dilatih pada lukisan Van Gogh, Picasso, dan Matisse. Ketika tiba saatnya untuk menyesuaikan dengan mode gambar, pengguna dapat memasukkan $[1,0,0]$ untuk van Gogh, [0, 1, 0] untuk Picasso], atau [0.33, 0.33, 0.33] untuk perpaduan ketiganya. Pendekatan yang bagus karena menghilangkan kebutuhan untuk melatih dan menyimpan banyak model untuk berbagai gaya, dan ini memberikan kebebasan kreatif dengan membiarkan user mencampur dan mencocokkan rangkaian gaya.

c. Arbitrary-StylePer-Model

Karakteristik umum dari kedua model transfer gaya tunggal dan multi-gaya adalah bahwa pendekatan tersebut hanya dapat menghasilkan gambar dalam gaya yang telah dilakukan pelatihan Model yang dilatih tentang pekerjaan Van Gogh tidak dapat menghasilkan gambar seperti Picasso tanpa melatih kembali seluruh jaringan. Transfer gaya sewenang-wenang oleh [9] mengubah itu. Model transfer gaya sewenang-wenang mengambil gambar konten dan gambar gaya sebagai input dan melakukan transfer gaya dalam sekali umpan maju. Intinya, model belajar mengekstrak dan menerapkan gaya apa pun pada gambar dalam sekali gerakan.

Neural Style Transfer (NST) adalah subset dari IB-AR (image based-artistic rendering). IB-AR terkait dengan proses abstraksi visual yang terlibat dalam penciptaan karya seni umum [4] dan digunakan untuk mengekspresikan ketidakpastian, mengomunikasikan ide-ide abstrak, dan membangkitkan imajinasi [10] dengan membahas kualitas rasional, emosional, dan kognitif dari pikiran manusia [4], [11] Pemisahan konten dari gaya pada abstraksi visual yang efektif dianggap sebagai faktor kunci untuk memungkinkan membedakan antara mekanisme yang digunakan untuk menangkap esensi gambar, di satu sisi, dan aspek desain yang mendorong daya tarik estetika untuk merangsang indera manusia [10], [12]

Implementasi $I B-A R$ biasanya membutuhkan pemrogram untuk membuat model desain serta ciri khas dan khas gaya artistik. Di sini, terdapat dua pendekatan umum [13] yaitu algoritma berbasis heuristic adalah paradigma yang berbasis pada fungsi rendering, pada dasarnya terdiri dari rendering berbasis stroke, teknik berbasis spasial, pemrosesan dan penyaringan gambar. Pendekatan selanjutnya adalah algoritma transfer gaya yaitu rendering berbasis contoh yang diarahkan untuk mempelajari atau mereproduksi gaya artistik dari contoh visual. Tipe ini sering terdiri dari model statistik dan skema optimisasi untuk menyeimbangkan aspek gambar konten dan gambar gaya dalam output gambar transfer gaya. Penggunaan berbasis histogram warna yang menyamakan mean dan varians antara gambar konten dan gambar gaya [14],[15]. 


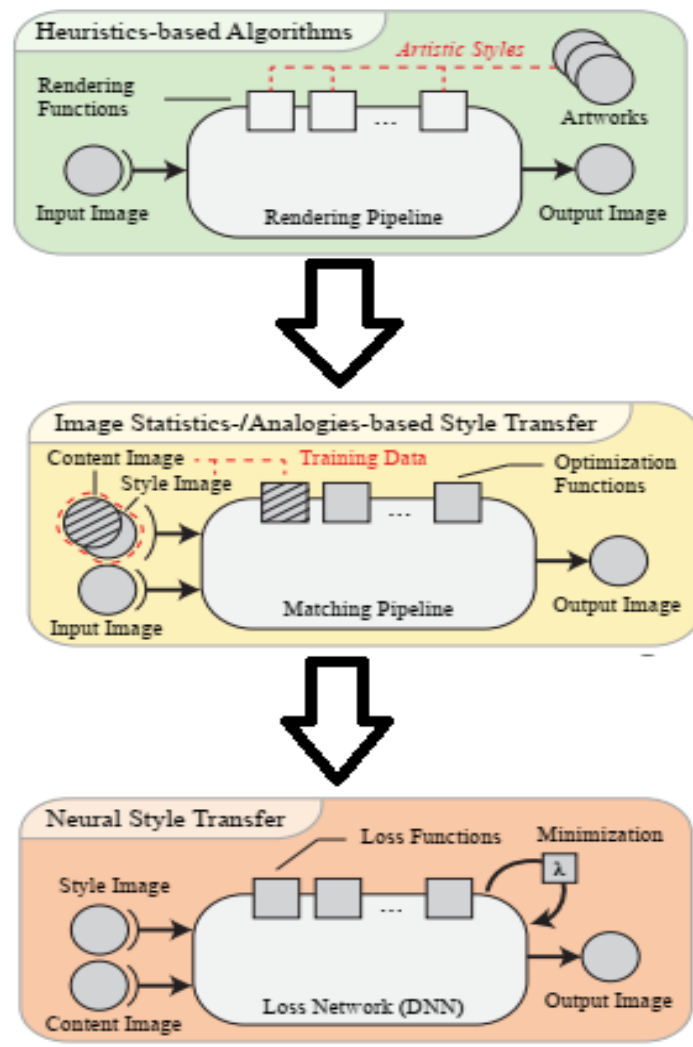

Gambar 2. Neural Transfer Style adalah Gabungan Algoritma Berbasis Heuristik dan Transfer Gaya Berdasarkan Statistik Gambar Atau Analogi [13]

Saat ini telah ada aplikasi komersial transfer gaya pada device smartphone seperti aplikasi Prisma [14] atau Ostagram [15], atau Deep Forger [16]. Transfer gaya mendapatkan perhatian peneliti karena tidak semua orang terlahir sebagai seniman. Beberapa lebih mahir dalam bahasa atau tugas lainnya. tetapi dengan kemajuan teknologi computer vision seperti transfer gaya, hampir semua orang dapat menikmati kesenangan dengan menciptakan berbagi karya artistik. Di sinilah kekuatan transformatif transfer gaya terletak. Seniman dapat dengan mudah meminjamkan estetika kreatif mereka kepada teknologi dengan memungkinkan orang lain, menciptakan representasi gaya artistik dan inovatif sendiri untuk membuat seperti karya asli. Fakta lain yang ada bahwa transfer gaya memberdayakan orangorang di seluruh dunia untuk bereksperimen dengan kreativitas mereka sendiri, [4] melihat pentingnya transfer gaya bermain di dunia seni komersial. Dalam beberapa bulan terakhir, Christie menampilkan karya seni AI yang dijual di salah satu lelang mereka dengan harga lebih dari \$430.000. Penelitian terkait transfer gaya juga telah menyebabkan banyak aplikasi industri yang sukses seperti aplikasi editor foto, industri game, virtual reality, seni komersial advertising.

NST adalah proses penciptaan seni. Seperti ditunjukkan dalam [3], [17], [18], definisi gaya adalah subyektif dan juga sangat kompleks, yang melibatkan pribadi preferensi, komposisi tekstur serta alat yang digunakan, akibatnya, sulit untuk mendefinisikan estetika kriteria untuk karya seni tansfer gaya. Untuk hasil transfer gaya yang sama, orang yang berbeda mungkin memiliki pandangan yang berbeda atau bahkan berlawanan. Meskipun demikian, tujuan penelitian ini adalah melakukan manipulasi gambar dengan menggunakan convolutional neural network (CNN) PerStyle-Per-Model (PSPM) seobjektif mungkin.

\section{METODOLOGI PENELITIAN}

Melatih model transfer gaya untuk mengomposisi ulang konten gambar dengan gaya yang lain memerlukan dua jaringan:

\subsection{Ekstraktor Fitur Pra Terlatih}

Extraktor fitur pra-terlatih digunakan untuk menghindari keharusan menggunakan dataset pelatihan. Kegunaannya muncul dari lapisan individu deep neural network yang dilatih untuk klasifikasi gambar untuk berspesialisasi dalam memahami fitur-fitur tertentu dari suatu gambar. Beberapa lapisan dilatih untuk mengekstraksi konten gambar (bentuk kucing atau mobil), sementara yang lain dilatih untuk fokus pada tekstur seperti sapuan kuas kecil pelukis atau pola fraktal alam. Hal ini telah ada dalam Model VGG-16 [6].

Transfer gaya mengeksploitasi hal ini dengan menjalankan dua gambar melalui jaringan saraf pra-terlatih, melihat output jaringan pra-terlatih di berbagai lapisan, dan membandingkan kesamaan setiap lapisan. Gambar yang 
menghasilkan keluaran serupa pada satu lapisan model pra-terlatih cenderung memiliki konten serupa, sementara mencocokkan keluaran di lapisan lain menandakan gaya yang serupa. Gambar 2 adalah tahapan ekstraktor fitur pra terlatih untuk kombinasikan gambar konten dan gambar gaya.

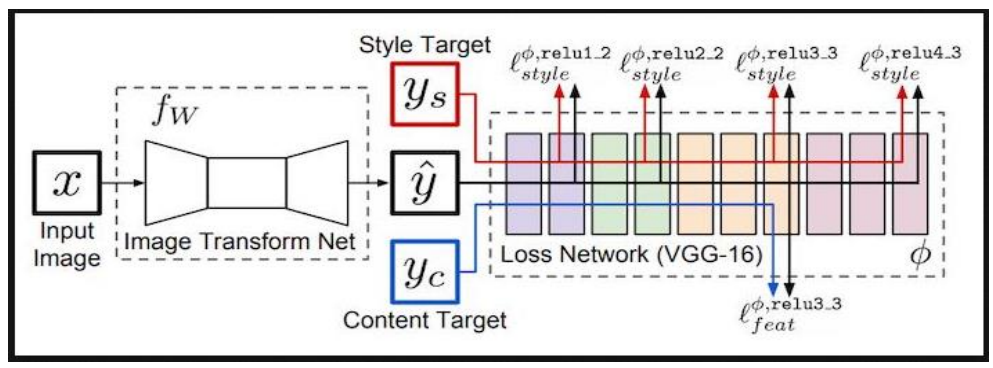

Gambar 3. Transfer Gaya dengan Convolutional Neural Network [6].

a. Pada awal pelatihan, satu atau lebih gambar gaya dijalankan melalui ekstraktor fitur pra-terlatih, dan output di berbagai lapisan gaya disimpan untuk perbandingan nanti.

b. Gambar konten kemudian dimasukkan ke dalam sistem. Setiap gambar konten melewati ekstraktor fitur praterlatih, dimana output diberbagai lapisan konten disimpan.

c. Gambar konten kemudian melewati jaringan transfer, yang menghasilkan gambar bergaya. Gambar bergaya juga dijalankan melalui ekstraktor fitur, dan output di kedua lapisan konten dan gaya disimpan.

Kualitas gambar bergaya ditentukan oleh loss functon yang bisa dikustom. Loss function berlaku untuk gambar konten dan gambar.gaya. Fitur konten yang diekstraksi dari gambar gaya dibandingkan dengan gambar konten asli. fitur gaya yang diekstraksi dibandingkan dengan yang dari dataset gambar gaya. Model VGG-16 yang telah dilatih sebelumnya pada dataset ImageNet dan digunakan untuk ekstraktor fitur. Setelah melewati setiap langkah bobot ekstraktor fitur pra-terlatih diperbaiki dengan menimbang menggunakan loss function, hal ini dapat melatih model untuk menghasilkan gambar output dengan gaya yang lebih ringan atau lebih berat.

\subsection{Jaringan Transfer}

Jaringan transfer adalah jaringan terjemahan gambar yang mengambil satu gambar sebagai input dan menghasilkan gambar lain sebagai output. Jaringan transfer biasanya memiliki arsitektur encode-decoder [6].

Sebuah operasi bernama transfer style saat pertama kali diperkenakan [1]. Penggunaan neural network pada transfer gaya akan digunakan mengekstrak fitur gambar. Parameter model ini tidak perlu diperbarui selama pelatihan karena menggunakan model VGG-16. CNN menggunakan beberapa lapisan neural network yang secara berturut-turut mengekstraksi fitur gambar. Secara teknis yang dilakukan $C N N$ pada transfer gaya dapat dilihat pada Gambar 4.

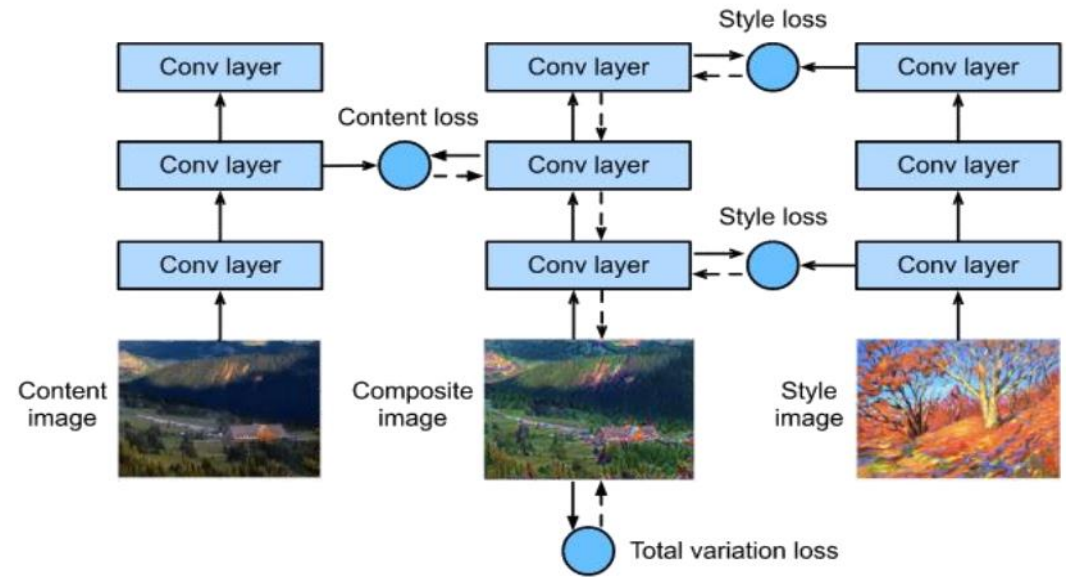

Gambar 4. Transfer Gaya dengan Convolutional Neural Network

Pada CNN mengandung tiga lapisan konvolusional. Lapisan kedua menampilkan fitur gambar konten, sedangkan output dari lapisan pertama dan ketiga digunakan sebagai fitur gaya. Selanjutnya, menggunakan forward propagation (gambar yang menunjukkan arah garis padat) untuk menghitung fungsi loss transfer gaya dan backward propagation (gambar yang menunjukkan arah garis putus-putus) untuk memperbarui parameter model, terus-menerus memperbarui gambar komposisi. Gambar komposisi adalah gambar output hasil dari transfer gaya. Loss function yang digunakan dalam transfer gaya umumnya memiliki tiga bagian :

a. Loss content digunakan untuk membuat gambar komposisi mendekati gambar konten sehubungan dengan fitur konten. Informasi tentang gambar konten apa pun akan diberikan secara sederhana oleh aktivasi neuron pada lapisan yang berbeda. Semakin dalam layer, semakin banyak informasi yang disimpannya. Ini dihitung sebagai 
jarak Euclidean antara aktivasi atau representasi fitur konten dan gambar yang dihasilkan pada lapisan yang berbeda. Formula 1 untuk loss content.

Keteranggan :

$$
\text { Lcontent }^{(\vec{p}, \vec{x}, l)}=\frac{1}{2} \sum_{i, j}^{n}\left(F_{i j}^{l}-P_{i j}^{l}\right)^{2}
$$

$\vec{p}$ Gambar asli

$\vec{x}$ Gambar generated

$l$ Layer

$F_{i j}^{l}$ Aktivasi filter $i^{\text {th }}$ pada posisi $j$ dalam representasi fitur $\vec{x}$

$P_{i j}^{l}$ Aktivasi filter $i^{\text {th }}$ pada posisi $j$ dalam representasi fitur $\vec{p}$

b. Loss Style digunakan untuk membuat gambar komposisi mendekati gambar gaya dalam hal fitur gaya. Mirip dengan loss content tetapi perbedaan antara keduanya adalah bahwa gaya gambar apa pun tidak hanya direpresentasikan seperti dalam hal konten, gambar gaya dihitung menggunakan gram matrix. Gram matrix berfungsi untuk mengukur tingkat korelasi antara saluran yang nantinya akan bertindak sebagai ukuran gaya itu sendiri. Korelasi yang lebih tinggi memberi gambaran tentang gaya suatu gambar. Rumus Gram Matrix pada Formula 2 dan rumus loss style pada Formula 3

$$
G_{i, k}^{l}=\sum_{k}\left(F_{i, k}^{l}-F_{j, k}^{l}\right)
$$

Keteranggan :

G Gram Matrix

$l$ Layer

$F_{i, k}^{l}$ Matriks Asli

$F_{j, k}^{l}$ Matriks Transpos

$$
\text { Lstyle }=\sum_{l} \sum_{i, j}\left(G_{i j}^{s, l}-G_{i j}^{P, l}\right)^{2}
$$

Keteranggan :

$G_{i j}^{s, l}$ Gram Matrix pada gambar gaya

$G_{i j}^{p, l}$ Gram Matrix pada gambar generated

c. Total variation loss membantu mengurangi noise pada gambar komposisi. Setelah memperhatikan bahwa loss style dan loss content menyebabkan output yang memiliki noise, maka total loss function (TV) juga termasuk dalam total loss dalam NST. Total loss ini memastikan kesinambungan dan kelancaran spasial dalam gambar yang dihasilkan untuk menghindari noise dan over pixel. Total loss adalah jumlah dari semua loss. Bobot ini menentukan seberapa besar dampak gaya atau konten pada total loss. Sederhananya, jika ingin memiliki lebih banyak pengaruh gaya daripada gambar inti konten pada gambar yang dihasilkan, beri bobot lebih tinggi pada loss style yang membuat total loss lebih bergantung pada loss style dan mengoptimalkan total loss akan lebih fokus pada mengoptimalkan loss style. Apabila ingin membuat gambar yang dihasilkan lebih mirip dengan gambar konten daripada gambar gaya, jadi mari tetapkan bobot untuk lebih banyak pengaruh konten daripada gambar gaya pada gambar yang dihasilkan, beri bobot lebih tinggi pada loss content yang membuat total loss lebih bergantung pada loss content dan mengoptimalkan total loss akan lebih fokus pada mengoptimalkan loss content.

Akhir pada pelatihan model, adalah menampilkan parameter model transfer gaya untuk mendapatkan gambar komposisi akhir. Pada Gambar 4 dapat dilihat antara bobot loss content, bobot loss style dan bobot total variation loss (TV) pada grafik epoch dan loss function, hasil yang baik pada transfer gaya berupa input gambar konten dipadukan dengan gambar gaya menghasilkan gambar komposisi yang memiliki kerapatan kecil di antara loss content, loss style dan total variation loss (TV).

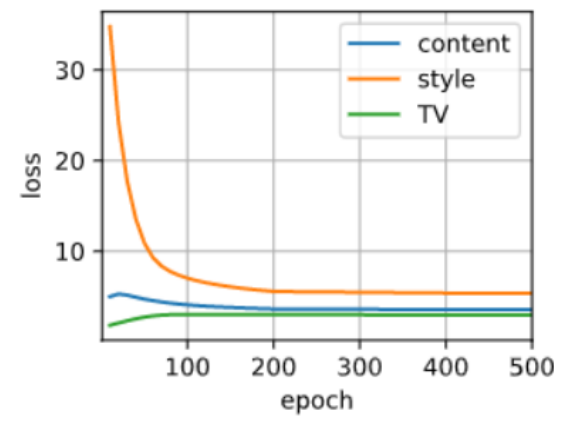

Gambar 5. Grafik Loss Function 


\section{HASIL DAN PEMBAHASAN}

Pada percobaan ini membutuhkan dua gambar sebagai input yaitu satu gambar konten dan satu gambar gaya. Pada Gambar 6, gambar konten adalah gambar peneliti dengan seekor kucing dan gambar gaya adalah lukisan yang biasa dikenal dengan nama "the scream".

$$
\text { Content Image }
$$
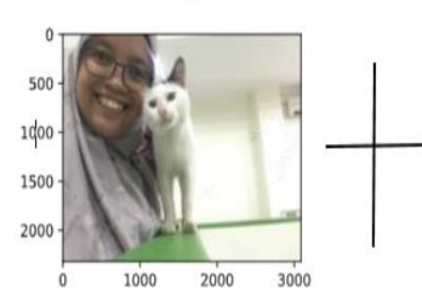

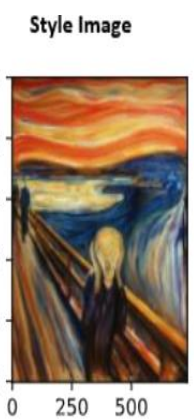

Hasil

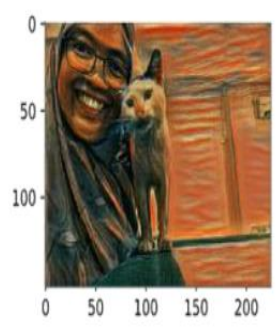

Gambar 6. Gambar Konten, Gambar Gaya, dan Hasil Transfer Gaya

Gambar 7 menggambarkan selama pelatihan, model terus mengekstraksi fitur gambar konten dan gambar gaya sehingga menjadi gambar komposisi dan menghitung loss function, hasil dapat dilihat pada gambar 8 menggunakan epoch 500 .

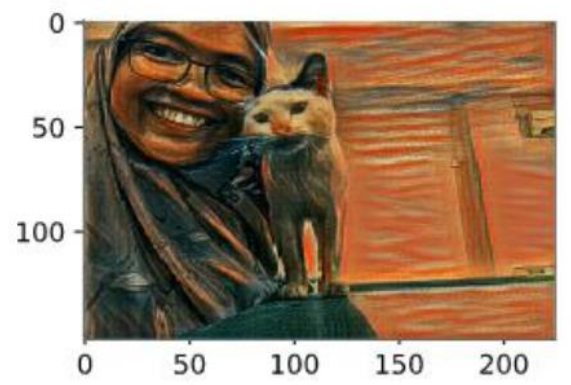

Gambar 7. Gambar komposisi mempertahankan gambar konten dengan memperkenalkan warna dari gambar gaya

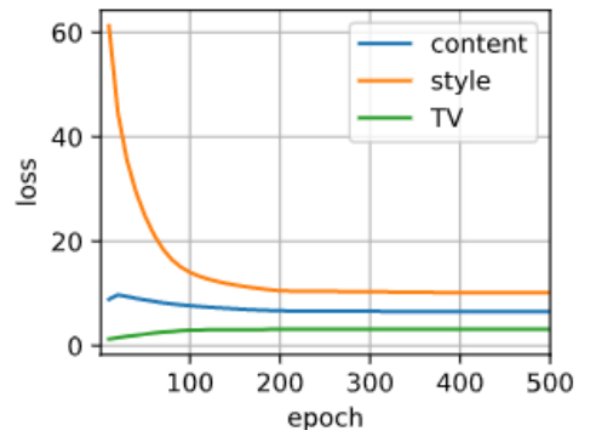

Gambar 8. Grafik dari Gambar 6 Transfer Gaya

Loss content membuat gambar gaya cenderung kehilangan gaya dan memadukan dengan gambar konten. Loss style membuat gambar konten cenderung kehilangan fitur konten dan memadukan dengan gambar gaya dan loss total variation adalah membantu mengurangi noise pada gambar akhir yaitu gambar komposisi.

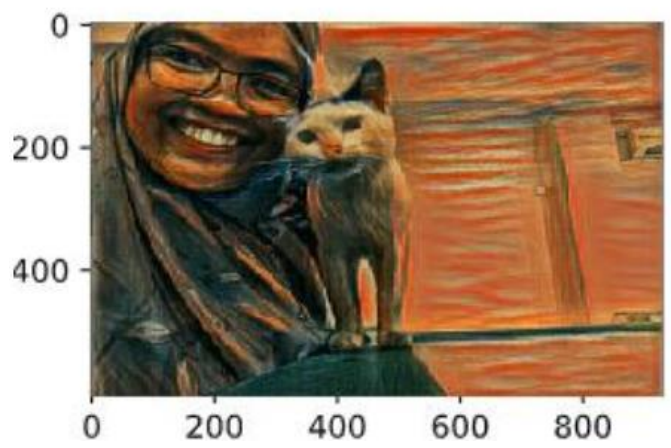

Gambar 9. Gambar Komposisi yang Lebih Jelas dengan Melatih Gambar Konten 900 X 600 pixel 
Building of Informatics, Technology and Science (BITS)

Volume 3, No 3, December 2021, Page 244-252

ISSN 2684-8910 (media cetak)

ISSN 2685-3310 (media online)

DOI 10.47065/bits.v3i3.1049

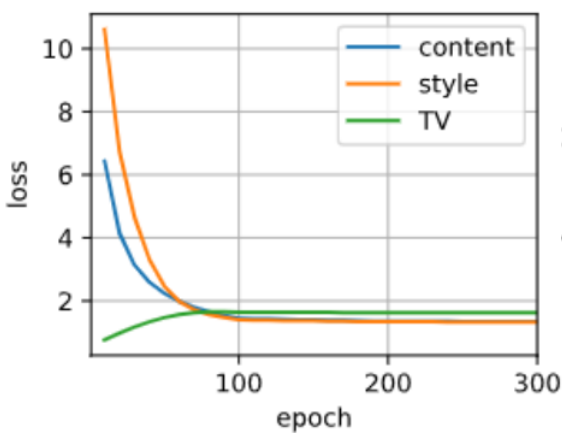

Gambar 10. Grafik gambar komposisi dengan melatih gambar konten 900 x 600 pixel

Resolusi pada gambar konten mempengaruhi hasil transfer gaya. Pada Gambar 10 kerapatan kecil menunjuki hasil transfer gaya yang baik adanya perpaduan yang pas penggunaan gambar konten resolusi 90x600 pixel. Gambar 11 adalah satu gambar konten yang diaplikasikan dengan berbagai macam gambar gaya.

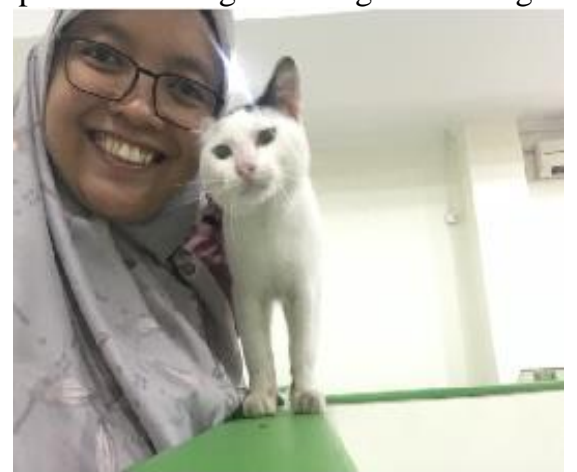

Gambar 11. Gambar Konten

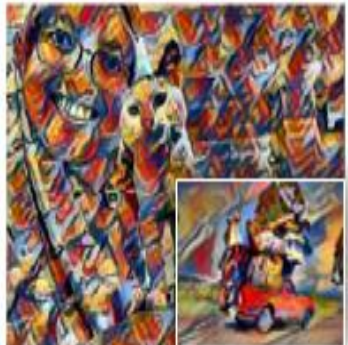

1

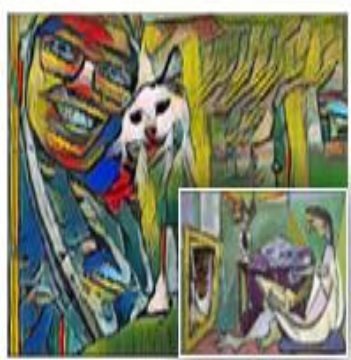

3

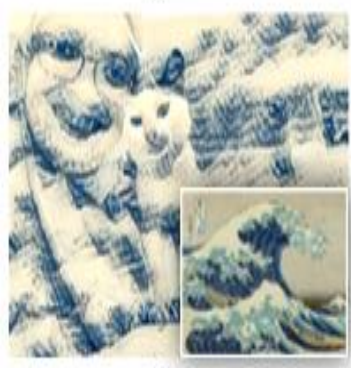

5

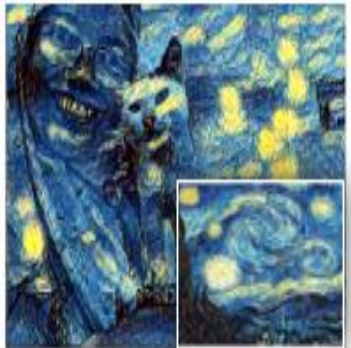

2

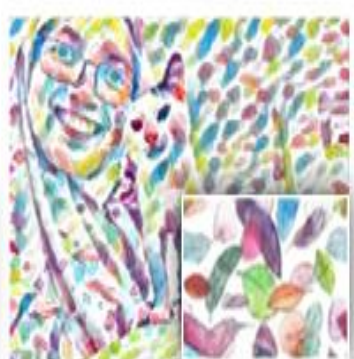

4

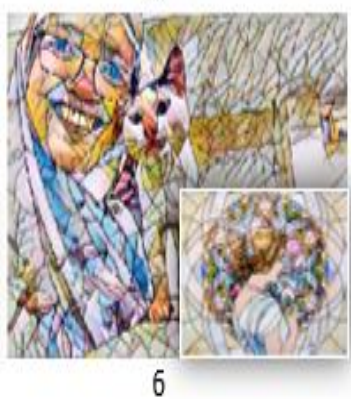

Gambar 12. Gambar Komposisi Foto Peneliti dengan Percobaan Berbagai Gambar Gaya 
Building of Informatics, Technology and Science (BITS)

Volume 3, No 3, December 2021, Page 244-252

ISSN 2684-8910 (media cetak)

ISSN 2685-3310 (media online)

DOI 10.47065/bits.v3i3.1049

Hasil transfer gaya dapat dilihat pada Gambar 12 dengan berbagai macam gaya yang detail gaya ada pada Tabel 1 , gambar konten Gambar 11.

Tabel 1. Detail Nama Gambar Gaya [19]

\begin{tabular}{cc}
\hline No & Nama Gaya \\
\hline 1 & Composition \\
2 & Starry Night \\
3 & La muse \\
4 & Feather \\
5 & The Wave \\
6 & Mosaic \\
\hline
\end{tabular}

\subsection{Optimalisasi dan Ekstensi Transfer Gaya}

Parameter model transfer gaya [6]. dengan pengembangan yang lama dan kemudian menerapkan model itu, peneliti menemukan bahwa hasilnya memperbaiki banyak kedipan. Bahkan perubahan resolusi dari 250 x 150 dan 900 x 600 pixel dan noise cukup untuk memperkenalkan konsistensi temporal yang mengganggu. Gambar komposisi dengan gambar konten dan gambar gaya gambar 6 untuk memperlihatkan hasil kestabilan transfer gaya.
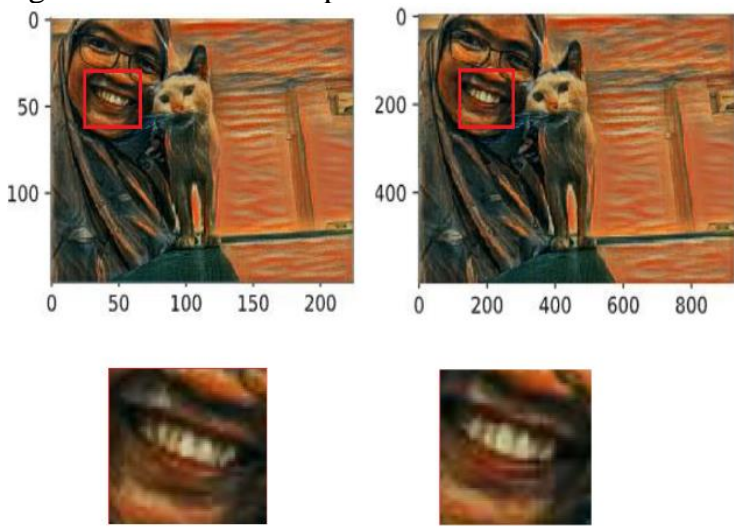

Gambar 14. Perbandingan Konsisten Hasil Transfer Gaya

Gambar 14 pada baris pertama adalah zoom in pada gambar pada baris kedua memperlihatkan konsisten hasil dengan gambar latih beda resolusi.

\section{KESIMPULAN}

Tulisan ini merupakan usaha untuk mengeksplorasi teknik neural transfer style dengan kategori Rekonstruksi Gambar Offline Berbasis Model-Optimisation (MOB-IR) PerStyle-Per-Model (PSPM) pengembangan dari [6]. Hasil yang telah dicapai adalah mencapai tujuan model yang terlatih dapat menyesuaikan dengan mode gambar apa pun hanya dengan satu iterasi bukan ribuan iterasi melalui jaringan dan untuk mendapatkan hasil transfer gaya yang memiliki gaya stabil nilai gaya estetika yang objektif. Evaluasi kualitatif penelitian ini bergantung pada estetika penilaian pengamat. Hasil evaluasi terkait dengan banyak faktor (mis., usia dan partisipan). NST adalah proses penciptaan seni. Penilaian gaya estetika adalah subyektif dan juga sangat kompleks, yang melibatkan pribadi preferensi, komposisi tekstur serta alat yang digunakan. Akibatnya, sulit untuk mendefinisikan estetika kriteria untuk karya seni transfer gaya. Untuk hasil transfer gaya yang sama, orang yang berbeda mungkin memiliki pandangan yang berbeda atau bahkan berlawanan. Transfer gaya mengubah cara berpikir tentang seni, apa arti orisinalitas dan bagaimana kita menyajikan seni di dunia nyata.

\section{REFERENCES}

[1] B. Gooch and A. Gooch, Non photorealistic rendering. Natick. MA, USA: A. K. Peters, Ltd, 2001.

[2] T. Strothotte and S. Schlechtweg, Non-photorealistic computer graphics: modeling, rendering, and animation. Morgan Kaufmann, 2002.

[3] P. Rosin and J. Collomosse, "Image and video-based artistic stylisation," Springer Sci. Bus. Media, vol. 42, 2012.

[4] and C. V. S. L. A. Gatys, A. S. Ecker, M. Bethge, "A Neural Algorithm of Artistic Style,” pp. 3-7, 2015.

[5] and V. L. D. Ulyanov, V. Lebedev, A. Vedaldi, "Texture networks: Feed-forward synthesis of textures and stylized images," Int. Conf. Mach. Learn., pp. 1349-1357, 2016.

[6] and L. F. J. Johnson, A. Alahi, "Perceptual Losses for Real-Time Style Transfer and Super-Resolution,” arXiv Prepr., 2016.

[7] C. Li and M. Wand, "Precomputed real-time texture synthesis with markovian generative adversarial networks," Eur. Conf. Comput. Vis., pp. 702-716, 2016.

[8] and M. T. A. Mordvintsev, C. Olah, "Inceptionism: Going deeper into neural networks," 2015. [Online]. Available: 
https://research.googleblog.com/2015/06/ inceptionism-going-deeper-into-neural.html.

[9] and L. M. H. Huang, H. Wang, W. Luo, "Real-Time Neural Style Transfer for Videos," pp. 783-791.

[10] and B. S. G. Amy A. Gooch, Jeremy Long, Li Ji, Anthony Estey, "Viewing Progress in Non-Photorealistic Rendering Through Heinlein's Lens," in In Proc. NPAR. ACM, New York, 2010, pp. 165-171.

[11] and T. S. Nick Halper, Mara Mellin, Christoph S. Herrmann, Volker Linneweber, "Psychology and Non-Photorealistic Rendering," Begin. a Beautiful Relationship. Proc. Mensch Comput., pp. 277-286, 2003.

[12] David H. Salesin, "Non-Photorealistic Animation \& Rendering," in NPAR, 2002.

[13] and E. R. Hasan Sheikh Faridul, Tania Pouli, Christel Chamaret, Jürgen Stauder, Alain Trémeau, "A Survey of Color Mapping and its Applications," 2014.

[14] I. P. Labs, "Prisma: Turn memories into art using artificial intelligence," 2016. .

[15] Ostagram, "Ostagram," 2016. .

[16] T. Henighan, "Spatial Control in Neural Style Transfer," 2017.

[17] G. Pan, D. Sun, R. Zhan, and J. Zhang, "Mural Sketch Generation via Style-aware Convolutional Neural Network," in CGI 2018: Proceedings of Computer Graphics International 2018, 2018, pp. 239-245.

[18] D. J. Semmo, Amir, Isenberg Tobias, "Neural Style Transfer: A Paradigm Shift for Image-based Artistic Rendering," in Proceedings of the Symposium on Non-Photorealistic Animation and Rendering, 2017. 